\title{
Distribution of Herbicide Resistances and Molecular Mechanisms Conferring Resistance in Missouri Waterhemp (Amaranthus rudis Sauer) Populations
}

\author{
John L. Schultz, Laura A. Chatham, Chance W. Riggins, Patrick J. Tranel, and Kevin W. Bradley*
}

A survey of soybean fields containing waterhemp was conducted just prior to harvest in 2012 to determine the scope and extent of herbicide resistance and multiple herbicide resistances among a sample of Missouri waterhemp populations. Resistance was confirmed to glyphosate and to acetolactate synthase (ALS), protoporphyrinogen oxidase (PPO), photosystem II (PSII), and 4-hydroxyphenylpyruvate dioxygenase (HPPD) inhibitors, but not to 2,4-D. Of the 187 populations tested, 186 exhibited resistance to chlorimuron. The proportions of populations with atrazine or glyphosate resistance were similar, with 30 and $29 \%$ of the populations surviving the $3 \times$ rates. Lactofen resistance was observed in $5 \%$ of the populations, whereas mesotrione resistance was only found in $1.6 \%$ of the populations. All populations tested were susceptible to 2,4-D at the $3 \times$ rate. At least $52 \%$ of the waterhemp populations tested exhibited resistance to herbicides from two mechanism of action. Resistance to atrazine plus chlorimuron as well as glyphosate plus chlorimuron was present in $29 \%$ of the populations. Three-way resistance, primarily comprised of resistance to atrazine plus chlorimuron plus glyphosate, was present in $11 \%$ of the populations. Resistance to herbicides from four mechanisms of action was found in $2 \%$ of the populations, and one population exhibited resistance to herbicides from five mechanisms of action. DNA analysis of a subsample of plants revealed that previously documented mechanisms of resistance in waterhemp, including the $\Delta \mathrm{G} 210$ deletion conferring PPO-inhibitor resistance, the $\operatorname{Trp}{ }^{574}$ Leu amino acid substitution conferring ALS-inhibitor resistance, and elevated 5-enolypyruvyl-shikimate-3phosphate synthase copy number and the Pro106Ser amino acid substitution resulting in glyphosate resistance, explained survival in many, but not all, instances. Atrazine resistance was not explained by the $\mathrm{Ser}^{264}$ Gly D1 protein substitution. Overall, results from these experiments indicate that Missouri soybean fields contain waterhemp populations with resistance to glyphosate, ALS-, PPO-, PSII-, and HPPD-inhibiting herbicides, which are some of the most common mechanisms of action currently utilized for the control of this species in corn and soybean production systems. Additionally, these results indicate that slightly more than half of the populations tested exhibit resistance to more than one herbicide mechanisms of action. Managing the current resistance levels in existing populations is of utmost importance. The use of multiple, effective herbicide modes of action, both preemergence and postemergence, and the integration of optimum cultural and mechanical control practices will be vital in the management of Missouri waterhemp populations in the future.

Nomenclature: 2,4-D; atrazine; chlorimuron; glyphosate; lactofen; mesotrione; waterhemp, Amaranthus tuberculatus (Moq.) Sauer var. rudis (Sauer); corn, Zea mays L.; soybean, Glycine max (L.) Merr.

Key words: Herbicide resistance, survey.

Waterhemp is the most prominent and troublesome weed in agronomic crops in Missouri, Iowa, and Illinois (Bradley 2013; Bradley et al. 2007; Hager et al. 2000; Legleiter and Bradley 2008; Rosenbaum and Bradley 2013; Waggoner and Bradley 2011). Its extended period of germination, rapid growth rate, and prolific seed production are all characteristics that have enabled this weed to thrive in current corn and

\footnotetext{
DOI: $10.1614 /$ WS-D-14-00102.1

* First and fifth authors: Graduate Student and Associate Professor, Division of Plant Sciences, 201 Waters Hall, University of Missouri, Columbia, MO 65211; second, third, and fourth authors: Graduate Student, Research Assistant Professor, and Professor (ORCID: 0000-0003-0666-4564), Department of Crop Sciences, University of Illinois, Urbana, IL 61801. Corresponding author’s E-mail: bradleyke@missouri.edu
}

soybean production systems (Hartzler et al. 1999, 2004; Sauer 1957). Waggoner and Bradley (2011) reported that waterhemp was found in $87 \%$ of the Missouri soybean fields that were surveyed at an average population density of 22 plants $\mathrm{m}^{-2}$, and resulted in yield losses up to $545 \mathrm{~kg} \mathrm{ha}^{-1}$. Corn and soybean can suffer substantial yield losses due to waterhemp. Hager et al. (2002) found that $10 \mathrm{wk}$ of waterhemp interference at population densities from 89 to 362 plants $\mathrm{m}^{-2}$ resulted in a $43 \%$ soybean yield loss. Cordes et al. (2004) reported waterhemp population densities from 82 to 445 plants $\mathrm{m}^{-2}$ resulted in a 10 to $36 \%$ corn yield reduction. Many producers rely primarily and often solely on herbicides for weed control; therefore, increasing selection pressure is placed on weed populations to evolve 
resistance (Powles 2008; Young 2006). Because waterhemp is dioecious, gene mutation is more likely and this species can transfer its genes easily from male to female plants via pollen (Costea et al. 2005; Hausman et al. 2011; Steckel 2007; Tranel et al. 2011).

As of 2014, numerous waterhemp populations within the United States have been reported to be resistant to herbicides from one or more of the following sites of action: inhibitors of EPSPS, ALS, PPO, PSII, and HPPD, and growth regulators (Heap 2014). One population of waterhemp from Illinois and one from Iowa evolved multiple resistances to herbicides from four sites of action (Bell et al. 2013; Heap 2014). Populations of waterhemp throughout Missouri, Iowa, and Kansas have evolved multiple resistances to herbicides from two or more modes of action (Heap 2014; Legleiter and Bradley 2008). In Missouri, waterhemp with resistance to glyphosate and ALS-, PPO-, or PSII-inhibiting herbicides has been documented (Heap 2014; Legleiter and Bradley 2008). In 2005, a waterhemp biotype that exhibited three-way resistance to glyphosate, ALS inhibitors, and PPO inhibitors was confirmed in Platte County, Missouri (Heap 2014; Legleiter and Bradley 2008).

Several mechanisms have been discovered to explain these herbicide resistances in waterhemp. ALSinhibitor resistance has been conferred mostly through a target-site point mutation, with $\operatorname{Trp}^{574}$ Leu amino acid substitution being most common (Patzoldt and Tranel 2007), but also through a non-target-site mechanism that appears to be metabolism-based (Guo et al. 2013; Warwick et al. 2010). Glyphosate resistance has been conferred through EPSPS gene amplification, a Pro ${ }^{106}$ Ser amino acid substitution in the EPSPS enzyme, and a non-target-site mechanism (Bell et al. 2013; Chatham et al. 2013; Nandula et al. 2013). Resistance to PPO-inhibiting herbicides is highly conserved and is conferred by a codon deletion at amino acid 210 in the PPX2 gene (Patzoldt et al. 2006). PSII-inhibitor herbicide resistance may be confirmed by a Ser ${ }^{264}$ Gly amino acid mutation in the psbA enzyme (Foes et al. 1998; Mechant et al. 2008), but non-target-site resistance to atrazine is common in waterhemp as well (Patzoldt et al. 2003). Ma et al. (2013) reported that, contrary to the aforementioned resistance mechanisms, there were no alterations in the HPPD sequence or HPPD expression in HPPDinhibitor-resistant waterhemp. Rather, the mechanism of resistance was determined to be enhanced oxidative metabolism (Ma et al. 2013).

Surveys are practical tools to gather important information to assist in educating producers on the current weed resistance status and distribution within a given geographic area (Beckie et al. 2000; Givens et al. 2009; Johnson and Gibson 2006; Rosenbaum and Bradley 2013). Rosenbaum and Bradley (2013) conducted a survey of weedy soybean fields at harvest in 2008 and 2009 to determine the extent and distribution of glyphosate resistance in Missouri waterhemp populations. They found that 69\% of the Missouri waterhemp populations sampled were resistant to glyphosate across 54 counties in the state (Rosenbaum and Bradley 2013). However, currently there is no information as to the extent of multiple herbicide resistances in Missouri waterhemp populations.

The objectives of this research were to determine the level of herbicide resistance and multiple herbicide resistances among a sample of Missouri waterhemp populations to herbicides spanning six mechanisms of action. In addition, some plants were evaluated for the presence of known resistance mechanisms to support whole-plant greenhouse data and to provide an indication of the frequencies at which these mechanisms exist.

\section{Materials and Methods}

Whole-Plant Resistance Evaluation. Plant Materials and Growth Conditions. In 2012, waterhemp seed samples were collected from 187 soybean fields across 57 counties in the primary corn and soybean production areas in Missouri. Sites for seed collection were chosen arbitrarily, but based on the presence of waterhemp in soybean fields just prior to soybean harvest. At each survey location, approximately 5 to 10 female waterhemp seed heads were harvested and the global positioning system coordinate was recorded (Figure 1). Mature seeds were gleaned from waterhemp seed heads and combined into a sample representative of that waterhemp population. Seeds were treated with a $50: 50$ water and commercial bleach solution for $10 \mathrm{~min}$, washed with water, suspended in a $0.15 \%$ agarose solution, and stored at $4 \mathrm{C}$ for $6 \mathrm{wk}$ prior to the start of the experiments to improve germination. Seeds from each population were broadcast into 25 - by $50-\mathrm{cm}$ greenhouse flats containing commercial potting medium (Premier Tech Horticulture, Quakertown, PA), which was used to cover the seedbed to a thickness of approximately $6 \mathrm{~mm}$ following planting. After emergence, one- to two-leaf seedlings were transplanted into cones $4 \mathrm{~cm}$ in diam and $4 \mathrm{~cm}$ deep (Cone-tainers, Stewe and Sons Inc., Tangent, OR) containing a $4: 1$ mixture of commercial potting

Schultz et al.: Waterhemp resistance survey - 337 

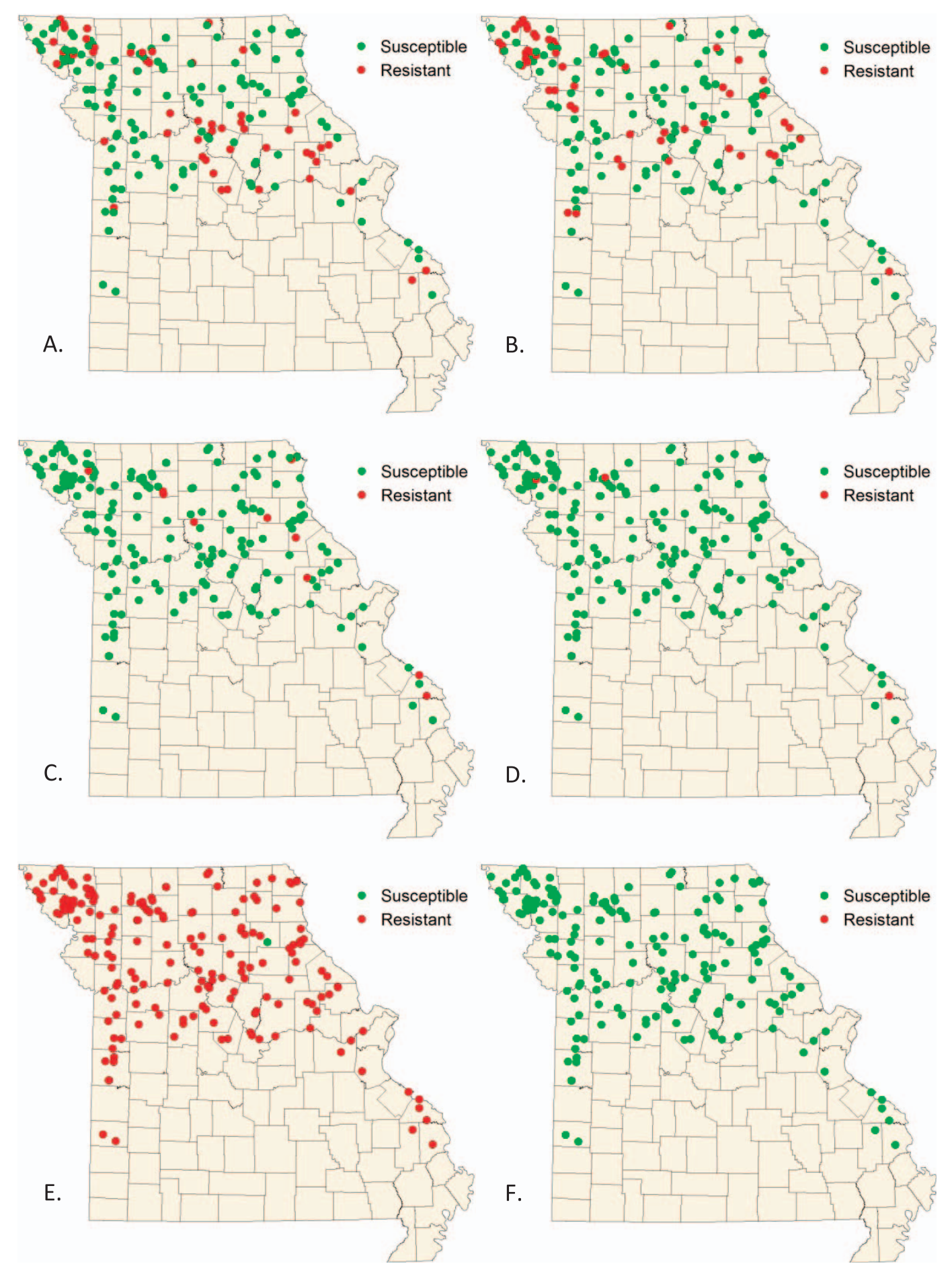

Figure 1. Distribution of waterhemp samples collected in the 2012 survey with resistances to the $3 \times$ rate of (A) glyphosate, (B) atrazine, (C) lactofen, (D) mesotrione, (E) chlorimuron, and (F) 2,4-D.

medium to sand. Plants were maintained in a greenhouse at 25 to $30 \mathrm{C}$, watered and fertilized as needed, and provided with artificial lighting from metal halide lamps $\left(600 \mu \mathrm{mol}\right.$ photon $\left.\mathrm{m}^{-2} \mathrm{~s}^{-1}\right)$ simulating a 16-h-photoperiod day.

Experimental Design. The trial design was a factorial arrangement of treatments in a randomized complete block with six replications (individual plants), where the factors were population, herbicide, and rate. The experiment was repeated once.

Treatment, Evaluation, and Data Collection. The herbicides and rates evaluated are listed in Table 1. Herbicide rates included the standard labeled rate $(1 \times)$ and three times the standard labeled rate $(3 \times)$ for each respective herbicide. A nontreated control was included from each population for comparison. 
Table 1. Sources of materials and rates used in the experiment.

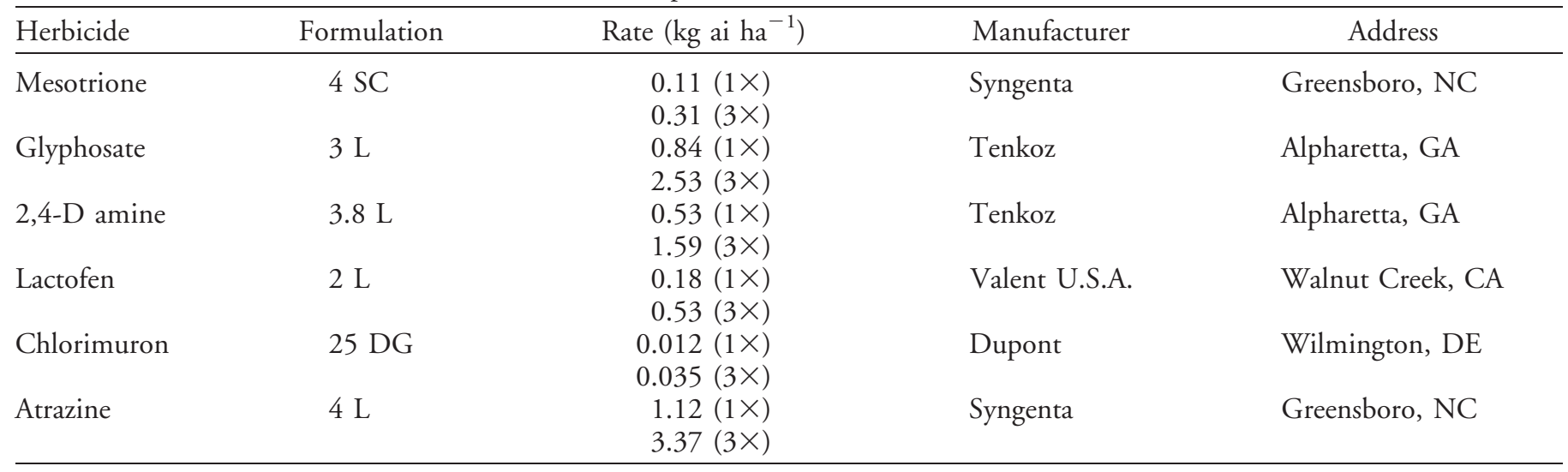

Treatments were applied when plants reached 8 to $12 \mathrm{~cm}$ in height, using a compressed-air laboratory spray chamber equipped with an 8001EVS nozzle (Teejet Spraying Systems, Wheaton, IL) delivering $220 \mathrm{~L} \mathrm{ha}^{-1}$ at $234 \mathrm{kPa}$. Resistance was characterized based on the number of plants that survived the $3 \times$ rate and were capable of continued growth $21 \mathrm{~d}$ after application (DAA) as suggested by Beckie et al. (2000) and Rosenbaum and Bradley (2013). Rosenbaum and Bradley (2013) classified waterhemp populations as resistant to glyphosate if survival was $60 \%$ or more at the $2 \times$ rate. In this experiment, waterhemp populations were considered resistant if $50 \%$ or more of the plants averaged across both runs survived the $3 \times$ herbicide application and were capable of growth and reproduction. Survivorship in response to each treatment was determined and recorded for each plant 21 DAA.

\section{Molecular Examination of Resistance Mechanisms.} Sample Preparation. Plant sampling to examine resistance mechanisms was conducted during the second run of the whole-plant screening, and selection of populations for sampling was guided in part based on results from the first screening. Prior to herbicide application, tissue samples were taken from the new growth of six plants from each of 26 potential PPOresistant populations to determine if the $\triangle \mathrm{G} 210$ codon deletion in the PPX2 gene was present. These same plants were tracked through the remainder of the experiment to determine survival or death following the application of the $3 \times$ rate of lactofen. Three weeks after the herbicide applications, additional tissue samples were arbitrarily collected from the new growth of 92 plants from 41 populations that survived the $3 \times$ rate of chlorimuron, from 93 plants from 36 populations that survived the $3 \times$ rate of glyphosate, and from 19 plants from populations in 19 different counties (one plant per county) that survived the $3 \times$ rate of atrazine to test for the mechanisms of resistance for these respective herbicides. Tissue was stored at $-80 \mathrm{C}$ until DNA extraction. All DNA was extracted from frozen leaf tissue using the hexadecyltrimethylammonium bromide method previously described by Doyle and Doyle (1990). Quality and quantity of DNA were examined using a spectrophotometer (NanoDrop 1000 spectrophotometer, Thermo Fisher Scientific, 81 Wyman St., Waltham, MA 02451), and samples were diluted to either $10 \mathrm{ng} \mathrm{ll}^{-1}$ for quantitative polymerase chain reaction (qPCR) or to $10 \%$ of the original concentration for all other downstream applications.

EPSPS Gene Amplification. Relative EPSPS copy number was determined using real-time qPCR as described previously (Délye et al. 2014; Ma et al. 2013).

EPSPS Point Mutation. Detection of the point mutation responsible for the Pro ${ }^{106}$ Ser substitution was carried out using a derived cleaved amplified polymorphic sequences (dCAPS) assay designed in the manner described by Délye et al. (2014). A portion of the EPSPS gene containing the codon at position 106 was amplified using the forward primer EPSf1 (5'-ATG TTG GAC GCT CTC AGA ACT CTT GGT-3') and reverse primer eps106wt-R3 (5'-CTC CAG CAA CGG CAA CCG CAA CTG TCC ATG-3'), which includes a single mismatch to introduce a $N c o$ I restriction site in wild-type alleles. After PCR, resulting amplicons were digested with the enzyme $N c o$ I (New England BioLabs Inc., 240 County Road, Ipswich, MA 01938-2723), and products were fractionated on a $2 \%$ agarose gel containing $0.5 \mu \mathrm{g} \mathrm{ml}^{-1}$ ethidium bromide and visualized with ultraviolet light.

Schultz et al.: Waterhemp resistance survey • 339 
ALS Trp ${ }^{574}$ Leu Mutation. The $\operatorname{Trp}^{574}$ Leu substitution in ALS results in the addition of an $M f e I$ recognition site. Primers AmALS-F2 (5'-TCC CGG TTA AAA TCA TGC TC-3') and AmALSR2 (5'-CTA AAC GAG AGA ACG GCC AG-3') were used to amplify the region of the ALS gene encompassing the $\operatorname{Trp}^{574}$ Leu substitution, and the amplified product was digested with MfeI, as described for kochia [Kochia scoparia (L.) Schrad.] (Foes et al. 1999).

ALS Sequencing. Regions A and B of ALS previously described by Foes et al. (1998) were amplified with PCR and visualized using gel electrophoresis to confirm the presence and size of the correct amplicon. The remaining PCR products were then purified (E.Z.N.A. Cycle Pure Kit, Omega Bio-Tek, Inc., 400 Pinnacle Way, Suite 450, Norcross, GA 30071) and sequenced (BigDye Terminator v3.1 Cycle Sequencing Kit, Applied Biosystems Inc., 850 Lincoln Centre Dr., Foster City, CA 94404) using both the forward and reverse primers for regions $A$ and $\mathrm{B}$. Products of the sequencing reaction were analyzed by the W.M. Keck Center for Comparative and Functional Genomics using an AB 3730xl DNA analyzer (Applied Biosystems Inc.). Sequences were then aligned to a waterhemp sequence from an ALS inhibitor-sensitive line (EF157818) in GenBank with MEGA6 (Tamura et al. 2013).

PPO $\triangle G^{210}$ Mutation. Allele-specific primers described previously by Lee et al. (2008) were used to screen samples for the codon deletion in the PPX2 gene that results in the deletion of Gly ${ }^{210}$.

D1 Ser ${ }^{264}$ Gly Mutation. A fragment of the chloroplast $p s b A$ gene, which encodes the D1 protein, was amplified with primers described by Foes et al. (1998). Following PCR, $5 \mu \mathrm{l}$ of each reaction was added to $20 \mu \mathrm{l}$ of a digestion mixture and incubated at $37 \mathrm{C}$ overnight. The digestion mixture contained the restriction enzyme BfaI (2.5 units $\left.\mu^{-1}\right), 1 \times$ concentration of the supplied buffer (New England Biolabs Inc.) and ultrapure water. Digested products were separated on a $1 \%$ agarose gel and visualized under ultraviolet light with ethidium bromide staining. Digestion with BfaI produces cleaved products only for the non-mutated form of the gene.

\section{Results and Discussion}

Whole-Plant Resistance Evaluation. Resistance was confirmed to herbicides from five of the six modes of action tested (Table 2; Figure 1). Of the 187 populations tested, 186 exhibited resistance to chlorimuron. Atrazine and glyphosate resistances were similar with 30 and $29 \%$ of the populations surviving the $3 \times$ rates, respectively. Lactofen resistance was observed in $5 \%$ of the populations whereas mesotrione resistance was only found in $1.6 \%$ of the populations. All populations tested were susceptible to $2,4-\mathrm{D}$ at the $3 \times$ rate.

Although the resistance threshold used in this experiment was $50 \%$ or greater survival to the $3 \times$ rate, data from the $1 \times$ rate were collected and included to show the potential future resistances in Missouri waterhemp populations (Table 2). There were no differences in the percentage of waterhemp populations that survived $1 \times$ and $3 \times$ rates of chlorimuron. High levels of resistance to chlorimuron and other ALS inhibitors have been well documented within the literature (Patzoldt et al. 2005; Patzoldt and Tranel 2007; Shoup et al. 2003). However, the number of populations resistant to the $1 \times$ rate of atrazine, glyphosate, lactofen, and mesotrione exceeded the level of resistance to the $3 \times$ rate of these same herbicides in every instance. Patzoldt et al. (2003) also observed differences in waterhemp survival between high and low application rates of atrazine. They attributed this response to a non-target-site mechanism of resistance. Unlike resistance to ALS inhibitors, current evidence suggests that glyphosate target-site mechanisms of resistance do not confer an absolute resistance level. In most cases of glyphosate resistance in Amaranthus species to date, overproduction of EPSPS reduces the ability of glyphosate to successfully bind to all EPSPS copies within the plant due to a higher ratio of EPSPS proteins to glyphosate (Powles 2010). Chatham et al. (2013) observed increasingly higher levels of glyphosate-resistant waterhemp control with each incremental increase in glyphosate rate across five separate waterhemp populations in the Midwest. Four of these populations were confirmed to have an elevated EPSPS copy number whereas one population had the Pro ${ }^{10} 6$ Ser amino acid substitution. An approximate $20 \%$ increase in control was also seen in a Mississippi glyphosate-resistant waterhemp population in response to increasing the glyphosate rate from $1 \times$ to $2 \times$ (Nandula et al. 2013). With regard to lactofen, the greater survival of waterhemp to the $1 \times$ compared to the $3 \times$ rate may have occurred because the resistance mechanism was overwhelmed and, since lactofen is a cell membrane disruptor, plant tissue may have been damaged to the extent that effective control was achieved. Thinglum et al. (2011) also reported increased control of PPO 
Table 2. Comparison of herbicide resistance in Missouri waterhemp populations.

\begin{tabular}{|c|c|c|c|c|}
\hline \multirow[b]{3}{*}{ Factor } & \multicolumn{4}{|c|}{ Resistance } \\
\hline & \multicolumn{2}{|c|}{$1 \times$ Rate } & \multicolumn{2}{|c|}{$3 \times$ Rate } \\
\hline & $\begin{array}{c}\text { No. of resistant } \\
\text { populations }\end{array}$ & $\begin{array}{c}\% \text { of } \\
\text { populations }\end{array}$ & $\begin{array}{c}\text { No. of resistant } \\
\text { populations }\end{array}$ & $\begin{array}{c}\% \text { of } \\
\text { populations }\end{array}$ \\
\hline \multicolumn{5}{|l|}{ Herbicide $^{a}$} \\
\hline Chlorimuron & 186 & 99.5 & 186 & 99.5 \\
\hline Lactofen & 20 & 11 & 10 & 5 \\
\hline Mesotrione & 27 & 14 & 3 & 1.6 \\
\hline 2,4-D Amine & 1 & 0.5 & 0 & 0 \\
\hline \multicolumn{5}{|l|}{ Two-way resistances ${ }^{b}$} \\
\hline 2,4-D + chlorimuron & 1 & 0.5 & 0 & 0 \\
\hline Atrazine + mesotrione & 18 & 10 & 3 & 1.6 \\
\hline Chlorimuron + glyphosate & 107 & 57 & 55 & 29 \\
\hline Chlorimuron + lactofen & 19 & 10 & 9 & 5 \\
\hline Chlorimuron + mesotrione & 27 & 14 & 3 & 1.6 \\
\hline Glyphosate + lactofen & 15 & 8 & 3 & 1.6 \\
\hline Glyphosate + mesotrione & 17 & 9 & 3 & 1.6 \\
\hline Lactofen + mesotrione & 2 & 1 & 1 & 0.5 \\
\hline Total populations with two-way resistance & 157 & 84 & 98 & 52 \\
\hline \multicolumn{5}{|l|}{ Three-way resistances ${ }^{b}$} \\
\hline 2,4-D + chlorimuron + mesotrione & 1 & 0.5 & 0 & 0 \\
\hline Atrazine + chlorimuron + glyphosate & 53 & 28 & 18 & 10 \\
\hline Chlorimuron + lactofen + mesotrione & 2 & 1 & 1 & 0.5 \\
\hline Glyphosate + lactofen + mesotrione & 2 & 1 & 1 & 0.5 \\
\hline Total populations with three-way resistance & 73 & 39 & 20 & 11 \\
\hline \multicolumn{5}{|l|}{ Four-way resistances ${ }^{b}$} \\
\hline Atrazine + chlorimuron + glypnosate + mesotrione & 13 & 7 & 3 & 1.6 \\
\hline Atrazine + chlorimuron + glypnosate + lactofen & 7 & 4 & 2 & 1 \\
\hline Atrazine + glypnosate + lactofen + mesotrione & 1 & 0.5 & 1 & 0.5 \\
\hline atrazine + chlorimuron + lactofen + mesotrione & 1 & 0.5 & 1 & 0.5 \\
\hline Chlorimuron + glyphosate + lactofen + mesotrione & 2 & 1 & 1 & 0.5 \\
\hline Total populations with four-way Resistance & 20 & 11 & 4 & 2 \\
\hline \multicolumn{5}{|l|}{ Five-way resistances ${ }^{\mathrm{b}}$} \\
\hline Atrazine + chlorimuron + glyphosate + lactofen + mesotrione & 1 & 0.5 & 1 & 0.5 \\
\hline Total populations with five-way resistance & 1 & 0.5 & 1 & 0.5 \\
\hline
\end{tabular}

a Appropriate adjuvants were added based on label recommendations for each respective herbicide.

${ }^{\mathrm{b}}$ Herbicide combination data is compiled from the single herbicide application data. Herbicides were not tank-mixed.

inhibitor-resistant waterhemp as the herbicide rate increased. Enhanced oxidative metabolism, as noted by Ma et al. (2013), is the only known mechanism of HPPD resistance in waterhemp to date. HPPD resistance was found in only $1.6 \%$ of the Missouri waterhemp populations, most likely due to the lack of frequency of HPPD-inhibiting herbicide use in Missouri corn and soybean production systems as compared to glyphosate, ALS-inhibiting herbicides, or atrazine.

Schultz et al.: Waterhemp resistance survey 


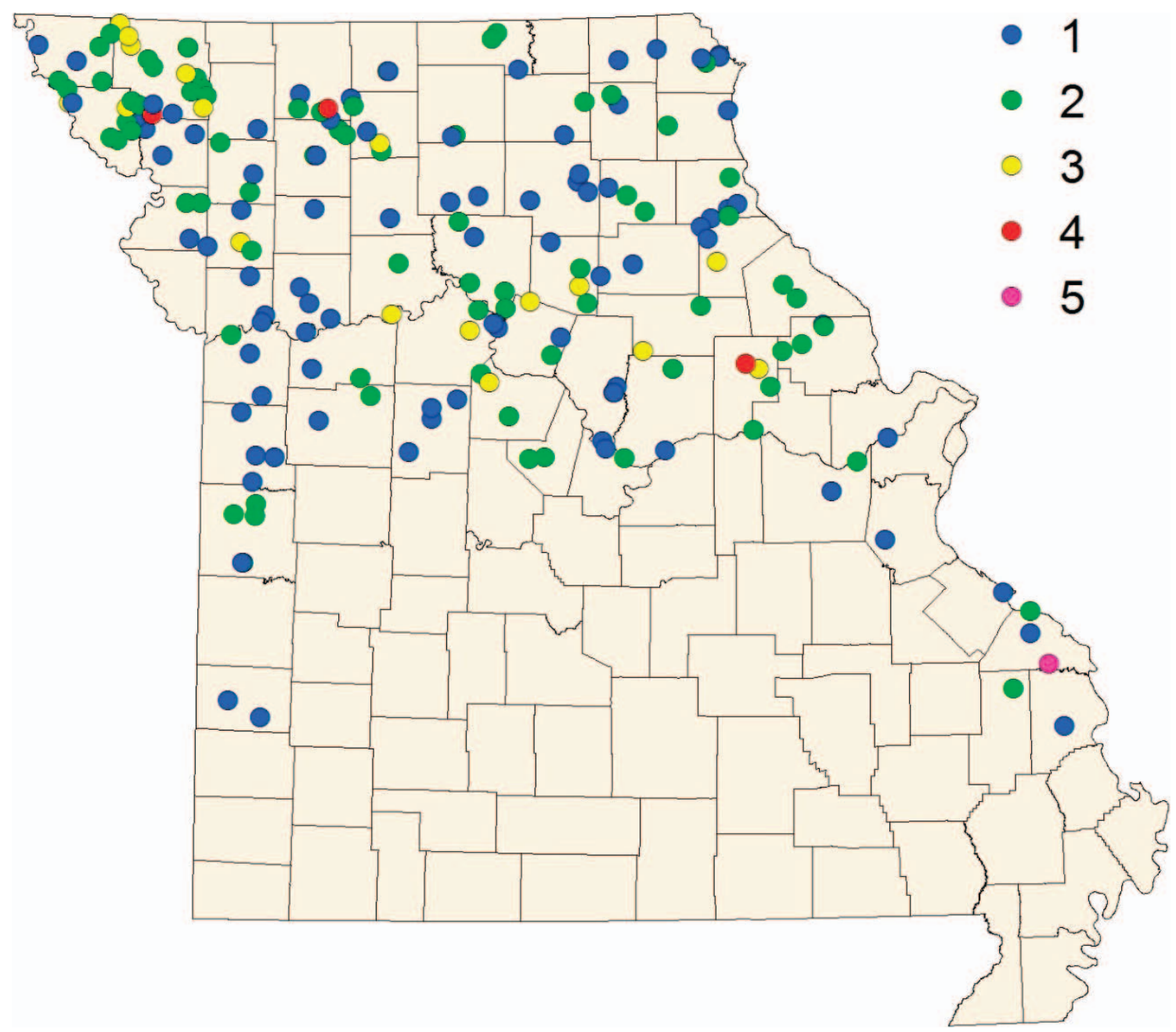

Figure 2. Distribution of waterhemp with multiple herbicide resistances collected in the 2012 survey.

At least $52 \%$ of the waterhemp populations tested exhibited resistance to herbicides from two mechanisms of action (Table 2; Figure 2). Resistance to atrazine plus chlorimuron as well as glyphosate plus chlorimuron was present in $29 \%$ of the populations. Three-way resistance was present in $11 \%$ of the populations with resistance to atrazine plus chlorimuron plus glyphosate present in $10 \%$ of the populations. Resistance to herbicides from four mechanisms of action was shown in $2 \%$ of the populations whereas only one population exhibited resistance to herbicides from five mechanisms of action.

Molecular Examination of Resistance Mechanisms. DNA analysis indicated that all sampled plants resistant to lactofen in the greenhouse experiment contained the $\Delta \mathrm{G} 210$ deletion mutation in the $P P X 2$ gene (Table 3). To date, this mutation remains the only known mechanism of PPO resistance in waterhemp. Based on anecdotal observations, it was expected that a higher percentage of the populations screened would have been resistant to lactofen. Therefore, plants were sampled prior to lactofen application so that plants that did not survive lactofen could be evaluated for the presence of the PPO $\Delta \mathrm{G} 210$ deletion. Of 135 plants sampled that did not survive lactofen, 37 contained the $\Delta \mathrm{G} 210$ deletion (data not shown). The use rates in this study were $0.18(1 \times)$ and $0.53(3 \times) \mathrm{kg}$ lactofen $\mathrm{ha}^{-1}$. Thinglum et al. (2011) reported increased control of PPO-resistant waterhemp as the lactofen rate increased. To determine the frequency of PPO-resistant waterhemp in populations from three states, Thinglum et al. (2011) used $0.11 \mathrm{~kg}$ of lactofen $\mathrm{ha}^{-1}$. The presence of the $\Delta G 210$ deletion in several plants that did not survive the $3 \times$ rate of lactofen indicates that the greenhouse data underestimated the frequency of resistance to PPO inhibitors.

Of the 92 plants sampled that exhibited resistance to chlorimuron, 75 contained the $\operatorname{Trp}^{574}$ Leu amino acid substitution (Table 3), with 20 and 55 being homozygous and heterozygous for the resistance allele, respectively (data not shown). All but one of 
Table 3. Analysis of known gene alterations in resistant and susceptible waterhemp plants following $3 \times$ rates of selected herbicide treatments.

\begin{tabular}{|c|c|c|c|c|c|c|}
\hline $\begin{array}{l}\text { Herbicide } \\
\text { treatment }\end{array}$ & $\begin{array}{c}\text { Total no. of } \\
\text { plants screened }\end{array}$ & $\begin{array}{l}\text { No. of resistant } \\
\text { plants screened }\end{array}$ & $\begin{array}{l}\text { No. of resistant } \\
\text { plants with } \\
\text { mutation }\end{array}$ & $\begin{array}{l}\text { No. of resistant } \\
\text { plants heterozygous } \\
\text { for mutation }\end{array}$ & $\begin{array}{l}\text { No. of sensitive } \\
\text { plants screened }\end{array}$ & $\begin{array}{c}\text { No. of sensitive } \\
\text { plants without } \\
\text { mutation }\end{array}$ \\
\hline Lactofen & $155^{\mathrm{a}}$ & $20^{\mathrm{a}}$ & $20^{\mathrm{a}}$ & $\mathrm{n} / \mathrm{a}^{\mathrm{b}}$ & $135^{\mathrm{a}}$ & $98^{\mathrm{a}}$ \\
\hline Chlorimuron & $92^{\mathrm{c}}$ & $92^{c}$ & $75^{\mathrm{c}}$ & $55^{c}$ & $\mathrm{n} / \mathrm{a}^{\mathrm{b}}$ & $\mathrm{n} / \mathrm{a}^{\mathrm{b}}$ \\
\hline Glyphosate & $93^{\mathrm{d}}$ & $93^{\mathrm{d}}$ & $19^{\mathrm{d}}$ & $16^{\mathrm{d}}$ & $\mathrm{n} / \mathrm{a}^{\mathrm{b}}$ & $\mathrm{n} / \mathrm{a}^{\mathrm{b}}$ \\
\hline Glyphosate & $93^{\mathrm{e}}$ & $93^{\mathrm{e}}$ & $82^{\mathrm{e}}$ & $\mathrm{n} / \mathrm{a}^{\mathrm{b}}$ & $\mathrm{n} / \mathrm{a}^{\mathrm{b}}$ & $\mathrm{n} / \mathrm{a}^{\mathrm{b}}$ \\
\hline
\end{tabular}

a Plants genotyped for a $\Delta \mathrm{G} 210$ deletion in the PP2XL enzyme.

${ }^{\mathrm{b}}$ Data not collected for this treatment.

${ }^{c}$ Plants genotyped for the mutation causing a $\operatorname{Trp}^{574} \mathrm{Leu}$ amino acid substitution in the acetolactate synthase enzyme.

d Plants genotyped for the mutation causing a Pro ${ }^{106}$ Ser amino acid substitution in the 5-enolypyruvyl-shikimate-3-phosphate synthase (EPSPS) enzyme.

e Plants analyzed for increased copies ( $\geq$ twofold) of the EPSPS gene.

${ }^{\mathrm{f}}$ Plants genotyped for the mutation causing a $\operatorname{Ser}^{264}$ Gly amino acid substitution in the D1 protein.

the populations evaluated for the $\operatorname{Tr}{ }^{574}$ Leu mutation had at least one plant with this mutation. Four plants from the population lacking this mutation were further evaluated by partial sequencing of the ALS gene. Mutations conferring $\mathrm{Ser}^{653} \mathrm{Asn}$ or $\mathrm{Ser}^{653} \mathrm{Thr}$ ALS substitutions were found in three of the four plants (data not shown). However, Patzoldt and Tranel (2007) reported that waterhemp biotypes with these ALS mutations were resistant to imidazolinone but not sulfonylurea herbicides (including chlorimuron, based on a leaf-disc assay). Observed resistance to chlorimuron in plants lacking the $\operatorname{Trp}^{574}$ Leu substitution, possibly including even those plants with substitutions at $\operatorname{Ser}^{653}$, may have been due to a non-target-site mechanism. Guo et al. (2013) found that a non-target-site, metabolismbased mechanism was responsible for ALS resistance in a waterhemp population from Illinois.

Ninety-three glyphosate-resistant plants from the greenhouse experiment were sampled to determine potential mechanisms of resistance. An elevated EPSPS copy number ( $\geq$ twofold) was found in 82 plants (Table 3). The Pro ${ }^{106}$ Ser substitution was found in 19 plants (Table 3), with 3 and 16 appearing to be homozygous and heterozygous for the mutation, respectively (data not shown). Some plants possessed both mechanisms: of those with an elevated EPSPS copy number, one appeared to be homozygous and 11 heterozygous for the $\mathrm{Pro}^{106} \mathrm{Ser}$ amino acid substitution. Of the resistant plants, four had neither an elevated EPSPS copy number nor the Pro ${ }^{106}$ Ser substitution. These plants may have a novel non-target-site mechanism of resistance or one similar to the GR waterhemp population from Mississippi documented by Nandula et al. (2013). Teaster and Hoagland (2014) also suggest that there are other, unknown, mechanisms of glyphosate resistance in Amaranthus species.

Of 19 plants that survived $3 \times$ atrazine, none contained the Ser ${ }^{264}$ Gly D1 substitution, which is the common basis of atrazine resistance in many weeds, including waterhemp (Foes et al. 1998). As previously reported, non-target-site atrazine resistance exists in waterhemp and confers a lower magnitude of resistance than does target-site resistance (Patzoldt et al. 2003). That there was a large difference in apparent atrazine resistance between the $1 \times$ and $3 \times$ atrazine rates, as discussed above, is consistent with the presence of a low-magnitude, non-target-site resistance mechanism in many if not all of the Missouri populations. It is also possible, however, that a target-site mutation other than Ser ${ }^{264}$ Gly is present in some of the Missouri populations (Powles and $\mathrm{Yu}$ 2010). Patzoldt et al. (2002) indicated that nontarget-site atrazine resistance was much more common than target-site resistance in waterhemp populations from Illinois as well.

In conclusion, results from these experiments indicate that Missouri soybean fields contain waterhemp populations with resistances to glyphosate and to ALS-, PPO-, PSII-, and HPPD-inhibiting herbicides, which comprise some of the most common mechanisms of action currently utilized for the control of this species in corn and soybean production systems. Additionally, these results indicate that slightly more than half of the populations tested exhibit resistance to herbicides from more than one mechanism of action. ALS-inhibiting herbicides are not effective in controlling many waterhemp populations and will likely continue to be unsuccessful in the future. ALS-inhibitor resistance in waterhemp was first documented in the United States in 1993 (Heap

Schultz et al.: Waterhemp resistance survey - 343 
2014). Twenty years later ALS-inhibitor resistance is present in most Missouri waterhemp, and in most other areas in the United States where waterhemp occurs (Heap 2014). Glyphosate and atrazine are still effective on some waterhemp populations, but resistances to these herbicides now occurs across such a wide geographical region that, based on previous experiences with ALS-inhibiting herbicide resistance in waterhemp, resistance in future waterhemp populations may be inevitable. Resistance to lactofen and mesotrione is present in only a small proportion of waterhemp populations in Missouri at this time, although resistance to lactofen may have been underestimated. As of yet, no resistance to 2,4-D has been discovered in Missouri waterhemp. The results from the DNA analysis of the subsample of plants that survived applications of glyphosate, PPO inhibitors, and ALS inhibitors revealed that many of the same mechanisms of resistance documented in previous research were present in Missouri waterhemp and, with the exception of PPO inhibitors, there appear to be multiple mechanisms that confer resistance. Looking to the future, it is unlikely that reversal of herbicide resistance is possible. Managing the current resistance levels in existing populations is likely the most plausible action. The use of multiple effective herbicides with different mechanisms of action, both PRE and POST, along with the integration of optimum cultural and mechanical control practices such as crop rotation, narrow row spacings, cover crops, and between-row cultivation will be vital to managing Missouri waterhemp populations in the future.

\section{Literature Cited}

Beckie HJ, Heap IM, Smeda RJ, Hall LM (2000) Screening for herbicide resistance in weeds. Weed Technol 14:428-445

Bell MS, Hager AG, Tranel PJ (2013) Multiple resistance to herbicides from four site-of-action groups in waterhemp (Amaranthus tuberculatus). Weed Sci 61:460-468

Bradley KW (2013) Herbicide-resistance in the Midwest: current status and impacts. Weed Sci Soc Am Abstr 271.

Bradley KW, Legleiter T, Hunter L, Nichols C, Foresman C (2007) The status of glyphosate-resistant waterhemp in Missouri. Champaign, IL: North Central Weed Sci Soc Abstr 192

Chatham LA, Riggins CW, Martin JR, Kruger GR, Bradley KW, Peterson DE, Jugulam M, Tranel P (2013) A multi-state study of the association between glyphosate resistance and EPSPS amplification in waterhemp. Champaign, IL: North Central Weed Sci Soc Abstr 127

Cordes JC, Johnson WG, Scharf P, Smeda RJ (2004) Lateemerging common waterhemp (Amaranthus rudis) interference in conventional tillage corn. Weed Technol 18: 999-1005
Costea M, Weaver SE, Tardif FJ (2005) The biology of invasive alien plants in Canada. 3. Amaranthus tuberculatus (Moq.) Sauer var. rudis (Sauer) Costea and Tardif. Can J Plant Sci 85:507-522

Délye C, Duhoux A, Pernin F, Riggins C, Tranel P (2014) Molecular mechanisms of herbicide resistance. Weed Sci 63:91-115

Doyle JJ, Doyle JL (1990) Isolation of plant DNA from fresh tissue. Focus 12:13-15

Foes MJ, Liu L, Bigue G, Stoller EW, Wax LM, Tranel PJ (1999) A kochia (Kochia scoparia) biotype resistant to triazine and ALS-inhibiting herbicides. Weed Sci 47:20-27

Foes MJ, Liu L, Tranel PJ, Wax LM, Stoller EW (1998) A biotype of common waterhemp (Amaranthus rudis) resistant to triazine and ALS herbicides. Weed Sci 46:514-520

Givens WA, Shaw DR, Johnson WG, Weller SC, Young BG, Wilson RG, Owen MDK, Jordan D (2009) A grower survey of herbicide use patterns in glyphosate-resistant cropping systems. Weed Technol 23:156-161

Guo J, Riggins CW, Hausman N, Hager AG, Riechers DE, Tranel P (2013) Non-target-site resistance to ALS inhibitors in waterhemp. Champaign, IL: North Central Weed Sci Soc Abstr 128

Hager A, Wax L, Simmons W, Sprague C (2000) Waterhemp management in Illinois agronomic crops. 2000 Illinois Agricultural Pest Management Handbook. Champaign, IL: University of Illinois Extension. Pp 91-100

Hager AG, Wax LM, Stoller EW, Bollero GA (2002) Common waterhemp (Amaranthus rudis) interference in soybean. Weed Sci 50:607-610

Hartzler RG, Battles BA, Nordby D (2004) Effect of common waterhemp (Amaranthus rudis) emergence date on growth and fecundity in soybean. Weed Sci 52:242-245

Hartzler RG, Buhler DD, Stoltenberg DE (1999) Emergence characteristics of four annual weed species. Weed Sci 47: 578-584

Hausman NE, Singh S, Tranel PJ, Riechers DE, Kaundun SS, Polge ND, Thomas DA, Hager AG (2011) Resistance to HPPD-inhibiting herbicides in a population of waterhemp (Amaranthus tuberculatus) from Illinois, United States. Pest Manag Sci 67:253-261

Heap I (2014) The International Survey of Herbicide Resistant Weeds. http://www.weedscience.org/summary/home.aspx. Accessed February 2, 2014

Johnson WG, Gibson KD (2006) Glyphosate-resistant weeds and resistance management strategies: an Indiana grower perspective. Weed Technol 20:768-772

Lee RM, Hager AG, Tranel PJ (2008) Prevalence of a novel resistance mechanism to $\mathrm{PPO}$-inhibiting herbicides in waterhemp (Amaranthus tuberculatus). Weed Sci 56:371-375

Legleiter TR, Bradley KW (2008) Glyphosate and multiple herbicide resistance in common waterhemp (Amaranthus rudis) populations from Missouri. Weed Sci 56:582-587

Ma R, Kaundun SS, Tranel PJ, Riggins CW, McGinness DL, Hager AG, Hawkes T, McIndoe E, Riechers DE (2013) Distinct detoxification mechanisms confer resistance to mesotrione and atrazine in a population of waterhemp. Plant Physiol 163:363-377

Mechant E, De Marez T, Hermann O, Bulcke R (2008) Resistance of Chenopodium album to photosystem II-inhibitors. Commun Agric Appl Biol Sci 73:913-917

Nandula VK, Ray JD, Ribeiro DN, Pan RZ, Reddy KN (2013) Glyphosate resistance in tall waterhemp (Amaranthus tubercu- 
latus) from Mississippi is due to both altered target-site and nontarget-site mechanisms. Weed Sci 61:374-383

Patzoldt WL, Dixon BS, Tranel PJ (2003) Triazine resistance in Amaranthus tuberculatus (Moq) Sauer that is not site-of-action mediated. Pest Manag Sci 59:1134-1142

Patzoldt WL, Hager AG, McCormick, Tranel PJ (2006) A codon deletion confers resistance to herbicides inhibiting protoporphyrinogen oxidase. Proc Natl Acad Sci U S A 103:12329-12334

Patzoldt WL, Tranel PJ (2007) Multiple ALS mutations confer herbicide resistance in waterhemp (Amaranthus tuberculatus). Weed Sci 55:421-428

Patzoldt WL, Tranel PJ, Hager AG (2002) Variable herbicide responses among Illinois waterhemp (Amaranthus rudis and $A$. tuberculatus) populations. Crop Prot 21:707-712

Patzoldt WL, Tranel PJ, Hager AG (2005) A waterhemp (Amaranthus tuberculatus) biotype with multiple resistance across three herbicide sites of action. Weed Sci 53:30-36

Powles SB (2008) Evolved glyphosate-resistant weeds around the world: lessons to be learnt. Pest Manag Sci 64:360-365

Powles SB (2010) Gene amplification delivers glyphosate-resistant weed evolution. Proc Natl Acad Sci U S A 107:955-956

Powles SB, Yu Q (2010) Evolution in action: plants resistant to herbicides. Ann Rev Plant Biol 64:360-365

Rosenbaum KK, Bradley KW (2013) A survey of glyphosateresistant waterhemp in Missouri soybean fields and prediction of glyphosate resistance in future waterhemp populations based on in-field observations and management practices. Weed Technol 27:656-663

Sauer J (1957) Recent migration and evolution of the dioecious amaranths. Evolution 11:11-31
Shoup DE, Al-Khatib K, Peterson DE (2003) Common waterhemp (Amaranthus rudis) resistance to protoporphyrinogen oxidase-inhibiting herbicides. Weed Sci 51:145-150

Steckel LE (2007) The dioecious Amaranthus spp.: : here to stay. Weed Technol 21:567-570

Tamura K, Stecher G, Peterson D, Filipski A, Kumar S (2013) MEGA6: Molecular Evolutionary Genetics Analysis version 6.0. Mol Biol Evol 30:2725-2729

Teaster ND, Hoagland RE (2014) Characterization of glyphosate resistance in cloned Amaranthus palmeri plants. Weed Biol Manag 14:1-10

Thinglum KA, Riggins CW, Davis AS, Bradley KW, Al-Khatib K, Tranel PJ (2011) Wide distribution of the waterhemp (Amaranthus tuberculatus) $\triangle \mathrm{G} 210$ PPX2 mutation, which confers resistance to PPO-inhibiting herbicides. Weed Sci 59:22-27

Tranel PJ, Riggins CW, Bell MS, Hager AG (2011) Herbicide resistance in Amaranthus tuberculatus: a call for new options. J Agric Food Chem 59:5808-5812

Waggoner BS, Bradley KW (2011) A survey of weed incidence and severity in response to management practices in Missouri soybean production fields. Champaign, IL: North Central Weed Sci Soc Abstr 80

Warwick SI, Sauder CA, Beckie HJ (2010) Acetolactate synthase (ALS) target-site mutations in ALS inhibitor-resistant Russian thistle (Salsola tragus). Weed Sci 58:244-251

Young BG (2006) Changes in herbicide use patterns and production practices resulting from glyphosate resistant crops. Weed Technol 20:301-307

Received July 18, 2014, and approved October 2, 2014. 